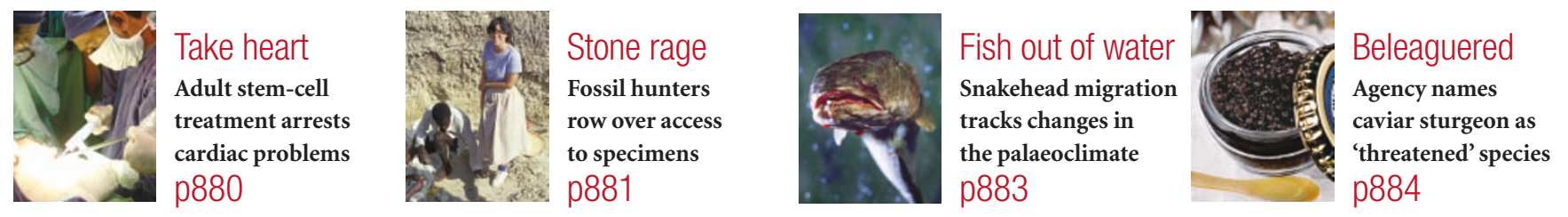

\title{
Young biologists rejected as NIIH budget squeezes training grants
}

\section{Meredith Wadman, Washington}

Budget pressures caused by flat funding at the US National Institutes of Health (NIH) are beginning to take their toll on research training, grant applicants say.

The prestigious NIH training grants that support nearly 18,000 graduate students and postdoctoral fellows are in trouble as the size of the stipend they offer increases, while the pot of money that funds them is unchanged.

Furthermore, most of the available money is already committed to the multi-year grants that were awarded when the biomedical research agency's budget was going up, earlier in the decade. The upshot is that applicants' chances of success have fallen sharply - by as much as half at some institutes.

At Cornell University's Weill Medical College in New York City, for example, one immunologist's application to renew a \$1.9-million, five-year NIH training grant supporting seven graduate students and postdocs was turned down earlier this month. William Muller, the senior scientist who wrote the grant application, had earlier received a written evaluation from the National Institute of Allergy and Infectious Diseases (NIAID) acknowledging an "excellent... application" from "high caliber preceptors" with "an excellent training record".

But two weeks ago, Muller got a call saying the grant would not be funded this year, because the institute was funding only $25 \%$

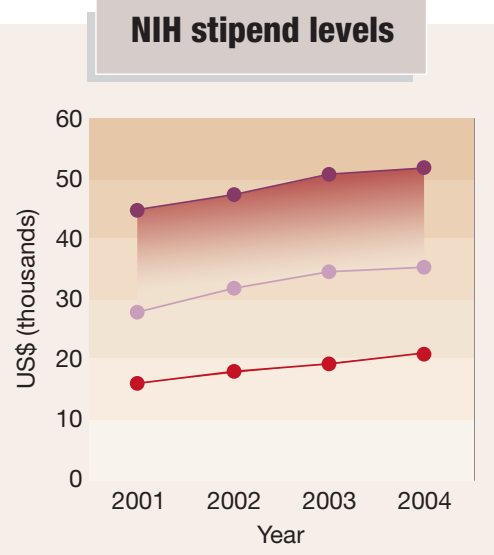

of training grant applications. Last year, 55\% of NIAID training grants were funded - a typical figure in recent years.

NIAID officials say that a relatively small number of training awards are made, and that the success rate fluctuates. After changes in the next few months, the final award rate for the year "could be anywhere from 25\% to $55 \%$ ", says John McGowan, director of the institute's extramural division. "Our institute is firmly committed to training," he says, "but if outgoing commitments go up and there are no new dollars, we will have to make some tough decisions."

The NIAID is not the only institute struggling to cope as the NIH deals with a 2004 budget increase of only $2.8 \%$ - less than the
$3.8 \%$ increase needed to maintain its purchasing power. At the National Cancer Institute, for example, officials speaking anonymously say that they expect to fund about half as many new institutional training grants as they did last year, when $46 \%$ of applications were supported. "It is not a good picture right now - especially for training,"

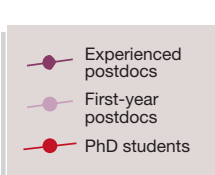
says one of them.

Walter Schaffer, the acting director of the NIH's Office of Extramural Programs who is in charge of training grants, says he does not have an overall 2004 figure for the success rates of training grant applications. "You are going to have to cut back on the total number of people you fund in order to finance cost-ofliving increases," says Schaffer.

The NIAID spent $\$ 51$ million on training grants in 2003, a figure that will increase slightly in 2004 . Overall, the NIH has $\$ 749$ million to spend on training grants in 2004; that would increase to $\$ 763$ million in 2005 if Congress fulfils President George Bush's budget request.

But the size of individual stipends given by the NIH has been increasing in response to complaints that many young scientists are underpaid and, in effect, exploited (see chart). After fulfilling commitments to existing five-year grants, including cost-of-living increases, little is left for new grants or competitive renewals, officials say.

\section{Trainee let down as allergy institute withdraws support}

Bidisha Dasgupta (right), a fifthyear graduate student in immunology at Cornell University's Weill Medical College, was "definitely disappointed" when she heard from her mentor William Muller last Friday that their lab had had its grant request turned down.The \$1.9-million National Institute of Allergy and Infectious Diseases grant would have funded her and six other trainees over the next five years.

Dasgupta, who studies blood-cell transmigration, has been supported by a training

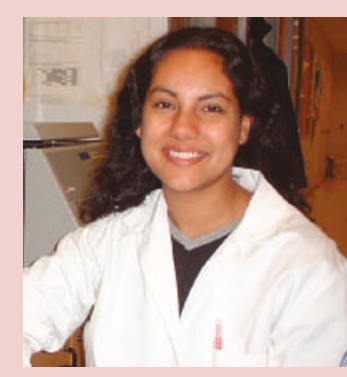

grant for the past two years. Now, Muller will have to find another way to fund her $\$ 25,000$ annual stipend.

"It underlines how much harder it is to get funding right now," says Dasgupta. "This was one of the more standard grants in our institution. And if this has been $\Delta$ cut, I am sure other grants will be even more competitive."

Dasgupta says that an NIH training grant is a valuable addition to a CV. A 2001 report written for the NIH by Georgine Pion of Vanderbilt
University in Nashville, Tennessee, found that the $8-10 \%$ of young scientists receiving these grants were subsequently more likely to obtain tenuretrack academic positions, find jobs at top-tier universities, obtain full research grants on their own and publish well-cited papers. These grants "are an incredibly effective way to train people", says Walter Schaffer, acting director of the NIH's Office of Extramural Programs.

For Dasgupta, the training grant's separate travel budget meant she could attend scientific conferences. She thinks the loss will also adversely affect Cornell, which "used the training grants as a recruiting tool". Meredith Wadman 